\title{
INTERNATIONAL COMMUNICATIONS: WHAT SHAPE TO COME?
}

\author{
Grorge E. AshLey*
}

\section{INTRODUCTION}

Overseas communications to and from the Unted States were a hundred years old in the Ig6os. The first cable capable of carrying telegraph signals across the Atlantic was laid in I866. The slow but steady growth in overseas communications which characterized much of the intervening time dramatically accelerated after World War II. Since then, the public has witnessed the installation of large capacity cables and satellites, providing vastly expanded communications facilities and services at ever-declining charges.

Telephone service is now available by direct circuits to eighty overseas countries or territories and via such points to 125 additional points. A telephone subscriber in this country can reach approximately $2 I_{5}$ million telephones, over ninety-six per cent of the world total. ${ }^{1}$ Operator dialing is already in effect to many countries, and direct customer dialing will be available next year. Telegraph service is available to even more countries. Over $25^{\circ}$ countries or territories throughout the world may be reached by telegrams sent from the United States.

Total annual revenues from this international communications business for the year 1967 were $\$ 311.5$ million, exceeding 1966 revenues by sixteen per cent. ${ }^{2}$ During I967 there were 12.3 million calls between the United States mainland and points overseas, up twenty-three per cent from the previous year. There were five times as many overseas calls from the United States in 1967 as there were just ten years ago. ${ }^{3}$ While message telegram revenues were only up slightly, consistent with the domestic pattern, teleprinter exchange revenues of the overseas telegraph carriers "advanced sharply." The net income of the Communications Satellite Corporation (Comsat), which provides facilities to the telephone and telegraph carriers, was up forty-seven per cent in I968 over the previous year. ${ }^{5}$

This ever-expanding service to the public has been accompanied by muchimproved quality and lower rates. For example, when service was first inaugurated from New York to London in 1927 , the rate for message telephone calls was $\$ 75$ for

*A.B. I947, LL.B. 1948, University of Missouri; General Attorney, American Telephone and Tele-, graph Company.

${ }^{1}$ American Tel. \& Tel. Co., The World's Telephones i-2 (ig68).

34 FCC ANN. Rep. 60 (I968).

${ }^{3}$ ATET, supra note I, at $\mathrm{I}$.

'FCC, supra note 2, at 60 .

ig68 Communications Satelitie Corp. Ann. Rep. 
the first three minutes. Rates have been progressively lowered, and classified schedules (i.e., person-to-person, station-to-station, etc.) have been introduced so that a New York-London call can be completed today for as little as $\$ 5.70$ at night and on Sunday. The initial rate to points throughout the world is not more than $\$ 12$, or $\$ \$_{5}$ if the call has to be switched via some foreign point. The rates for private line services, used primarily by the Defense Department, have also been drastically reduced. For example, a full period telephone-grade circuit from San Francisco to Hawaii was $\$ 20,000$ per month in 1957 and is $\$ 8,400$ today; for New York to London it dropped from $\$ 20,000$ in Ig66 to $\$ 13,744.30$ today. ${ }^{6}$

Extensive reductions have also been made in the rates for telegraph services. For example, the private line teletypewriter rates for a circuit from San Francisco to Hawaii dropped from $\$ 7,000$ in 1957 to $\$ 2,500$ today, and from New York to London from $\$ 8,500$ in 1964 to $\$ 2,400$ today.

This record of achievement has been accomplished by a healthy, financially strong industry. All the international telephone and telegraph carriers are prospering, and Comsat has already moved into the black. Despite this fine record, the question of the appropriate structure for our international communications has been the subject of numerous high level government studies in recent years. The report ${ }^{7}$ of the latest of these, the Task Force on Communications Policy established by President Johnson in August 1967, was recently released by the present administration, which, however, made it clear that it "in no way endorses the recommendation of the Task Force or its analysis of the issues." The recommendations included one for a restructuring of U.S. international communications by the formation of a single entity to own and operate all transmission facilities. In view of the proven performance of the industry, the need for such drastic governmental action is, at the least, open to serious question. A review of the international telecommunications industry, both present and past, indicates why earlier recommendations for restructuring the industry have been rejected and why such a proposal warrants further critical analysis.

\section{I}

\section{Present Structure of the Industry}

The Long Lines Department of the American Telephone and Telegraph Company (AT\&T) operates telephone service from the U.S. mainland to overseas points. It does not operate as a carrier in any overseas country, connecting instead with foreign telecommunications companies and administrations. Overseas telegraph

\footnotetext{
'The U.S. carrier's share dropped from $\$ 10,000$ to $\$ 6,000$.

'President's Task Force on Communications Policy, Final Report (rg68) [hercinafter cited as TASK FoRCE REPORT].

${ }^{8}$ Letter from Richard M. Nixon to James L. Broyhill of the Subcommittee on Communications and Power of the House Committee on Interstate and Foreign Commerce, May 20, 1969.
} 
business, and private line alternate voice-data service (except for certain "grandfather" rights of AT\&T), are provided principally by ITT World Communications, Inc., a subsidiary of International Telephone and Telegraph Corporation (ITT), RCA Global Communications, Inc. (RCA Globcom), a subsidiary of Radio Corporation of America, and Western Union International (WUI), formed several years ago by the divestiture of the overseas portion of the business of The Western Union Telegraph Company. ITT World Communications, Inc. (ITT World Com.) has recently acquired Press Wireless, Inc., a smaller specialized carrier, and there is pending an application by RCA Globcom to acquire Tropical Radio Telegraph Company, which operates principally to Central America. ${ }^{9}$ Small additional amounts of overseas telegraph communications are also provided by the U.S.-Liberia Radio Corporation, a subsidiary of The Firestone Tire \& Rubber Company, and by The French Cable Company, the only foreign-owned company to engage in this business in the United States. Overseas television service is provided by AT\&T, ITT World Com., RCA Globcom, and WUI on a rotating basis. Transmission facilities via satellite are provided to the carriers by Comsat.

\section{II}

\section{History of United States International Communications}

A. International Telegraphy by Cable and Radio

In 1866, the Anglo-American Telegraph Company, a British company which was organized by Cyrus W. Field, laid the first successful transatlantic telegraph cable. Transoceanic communication of telegraph signals by radio was first achieved by Marconi in Igor. International telephone, because of its wider bandwidth, became feasible only later and when radio communication became more advanced. Successful experimentation began shortly before World War I. The first public radio telephone circuit was established between New York and London in 1927, and service was extended to the European continent the next year.

Technological developments and their timing go far toward explaining the present structure of the industry. Due to technical limitations on the distances over which signals could be transmitted, and the small volume of communications that could be passed over individual cables, as well as international political considerations, numerous companies were formed and numerous cables laid for telegraph service.

The British dominated the world cable networks in the early years. American companies first entered the international communications field when the American Telegraph \& Cable Company laid two cables between Canso, Nova Scotia, and Penzance, England, in I88ז and I882. These cables were leased to The Western Union Telegraph Company. Commercial Cable Company, organized in 1883 , also

\footnotetext{
${ }^{\circ}$ Application of RCA Global Communications, Inc., FCC File No. 537-C4-TC(4)-69 (1969).
} 
entered the field in competition with Western Union and British interests with the laying of two cables between Nova Scotia and Ireland in r884. All America Cables \& Radio, Inc., entered the field in the 1880 s and along with Western Union rapidly developed service between the continental United States and the West Indies, Central America, and South America. In I902, The Commercial Pacific Cable Company laid a cable between San Francisco and Hawaii, which was extended to the Philippines in r903. In rgro Western Union laid a cable between New York and Penzance, England, via Newfoundland, but was forced to sell this cable to Anglo-American because of the latter's exclusive rights in Newfoundland. In IgIr, Western Union leased this cable, and four other transatlantic cables owned by Anglo-American, for a period of ninety-nine years. It was not until 1921, when regenerators were developed, that American companies laid cables directly to Europe.

As stated above, transoceanic communication by radiotelegraph was first achieved by Marconi on December 12, Igor. Development first centered on ship-to-shore service. Overseas commercial radiotelegraph came considerably later. The dominant U.S. company in the early years of radiotelegraph was American Marconi, which was controlled by British interests. With the advent of World War I, just as Marconi was ready to place powerful transmitters in service in the United States for commercial use, the U.S. Navy assumed operation of all U.S. high-powered stations built for transoceanic communications. Under its wartime control, the Navy was able to combine conflicting patent interests and to carry on transoceanic telegraphy. Thereafter, the government fostered the organization of Radio Corporation of America (RCA), which was incorporated on October $I 7$, IgIg, to solve the patent tangle over radio and to keep American radio communications free of foreign control. After RCA was organized, it purchased the assets and patent rights held by American Marconi and entered into cross-licensing agreements with other companies. With these rights, RCA established direct radiotelegraph circuits to many countries. Thus, radio circuits gradually began to compete with cable circuits.

With the advent of transoceanic radio, concern arose that the established cable companies might hamper the development of radio as a medium for transoceanic communications. This resulted in the erection of statutory obstacles to the ownership or control of radio companies by cable companies. ${ }^{10}$ With the availability of sufficient high-frequency radio channels, carriers in addition to RCA were licensed to use radio, and still later the establishment of parallel circuits by different companies was authorized.

The dispute over competitive routes for telegraph service reached its climax in the famous "Three-Circuits" case. ${ }^{11}$ Here the FCC granted Mackay Radio's

\footnotetext{
${ }^{10}$ Communications Act of I934, 47 U.S.C. $\$ 3 I 4$ (1964).

${ }^{11}$ FCC v. RCA Communications, Inc., 346 U.S. 86 (I953).
} 
application to duplicate RCA's radio telegraph circuits to Portugal and Holland, but denied it authority to duplicate RCA's circuit to Surinam. The FCC found that, under the "national policy . . . favoring competition," the "public interest" test of the Communications Act required competition in the common carrier field where it is "reasonably feasible," even though it had not concluded, based upon the evidence, that such competition would result in better service or lower rates. ${ }^{12}$ The Supreme Court reversed and remanded the case, saying: "Merely to assume that competition is bound to be of advantage, in an industry so regulated and so largely closed as this one, is not enough."13 On the basis of more specific findings, the Commission on remand again held in favor of Mackay on the same two of its three applications. ${ }^{14}$

\section{B. Overseas Telephone Service}

Whereas several competing companies developed in the international telegraph field, overseas telephone communication was developed largely by AT\&T as an extension of its domestic service. As indicated previously, the early cables could not transmit the human voice overseas, but beginning in I927 overseas telephone service was provided by radio. However, almost at the very time that commercial service started by radio, AT\&T in conjunction with the British Post Office started development work on a transatlantic cable that could handle voice communications. The proposed cable was to have been nonrepeatered and of very limited bandwidth. The project went as far as manufacturing and laying test lengths of cables. AT\&T established a Canadian subsidiary, Eastern Telephone and Telegraph Company, which secured a right of way between the U.S.-Canada border and Newfoundland. The project was dropped in r93I, largely because of economic conditions.

Although some development work on long submarine cables continued at Bell Laboratories, it was not until after World War II that a major breakthrough occurred. In 1947 Bell Laboratories started a project to develop underwater repeaters. This project led to the laying of a Key West-Havana cable system in 1950 employing repeatered twin cables providing twenty-four voice-grade circuits.

The development of a repeatered submarine cable capable of such increased capacity was the beginning of a revolutionary explosion in overseas communications. Prior to that time there had been steady progress and growth, but the narrow bandwidth of the available cables and the inherent instability of high frequency radio had been inhibiting factors. In the past two decades, beginning with the successful installation of repeatered cables, overseas communications have truly come into their own.

\footnotetext{
${ }^{12}$ Mackay Radio \& Tel., Inc., 15 F.C.C. 690 (I95I).

${ }^{18} 346$ U.S. at 97 .

${ }^{14}$ Mackay Radio \& Tel., Inc., I9 F.C.C. I3I4 (1955), aff'd, RCA Communications, Inc. v. FCC, 238 F.2d 24 (D.C. Cir. I956), cert. denied, 352 U.S. 1004 (I957).
} 
In 1956, the first broadband, repeatered transatlantic cable (commonly referred to as TAT-r) was laid, providing thirty-six voice-grade circuits between North America and the United Kingdom. Additional cables followed in rapid succession (e.g., Alaska, 1956; Hawaii, 1957; France, 1959; Puerto Rico, 1960). The availability of high-quality circuits resulted in a veritable explosion in demand (e.g., United States-United Kingdom messages increased about ninety per cent the first year TAT-I was in operation).

Subsequent years saw frequent increases in the capacity of the cables, improvement in their design, and additional developments to improve their utilization (for example, Time Assignment Speech Interpolation (TASI) equipment, which by taking advantage of the idle time in voice conversations, effectively doubles the call-carrying capacity of a number of circuits). The latest type of cable, laid to St. Thomas last year and currently in the process of being laid across the Atlantic (TAT-5), is a single two-way cable, powered by transistors instead of vacuum tubes, which provides 720 voice-grade channels.

Modern high capacity cables span not only the Atlantic but also the Pacific, and many are being built by other countries independently of U.S. participation, such as between France and Israel by the French, and Britain and South Africa by the British. Wherever such cable communications are provided they are of a quality comparable to that enjoyed domestically.

Another radio technique which provides high quality communications over relatively short distances is over-the-horizon radio, using microwave frequencies by a tropospheric scatter technique. Such systems were placed in service between Florida and Cuba in 1957 and between Florida and the Bahamas in 1960.

\section{Contractual Arrangements}

Before turning to the institution of communications via satellite, a word should be said about the contractual arrangements which developed along with the facilities just described: In the case of high-frequency radio the arrangements were quite simple. The communications agency at each end established its own transmitting and receiving facilities operating on common frequencies with its correspondent, and an agreement was reached for the division of revenues derived from the service, generally on a fifty-fifty basis. Where, however, intermediate facilities were required to provide service, such as in the case of submarine cables, special contracts had to be negotiated for their construction, ownership, and use, still retaining financial interests substantially in accord with use.

For example, the second transatlantic cable (TAT-2) was constructed under an agreement between the French Administration for Posts, Telegraphs and Telephones, the German Bundespost, and AT\&T. AT\&T was assigned the responsibility of laying the cable. It was agreed that the cable would be landed at Penmarch, France, and that the French Administration would provide the German Bundespost with 
facilities transiting France. It was agreed that the cable would be paid for and owned, in common, in certain undivided shares by the three parties, commensurate with use, and that maintenance and operating costs would be paid by the parties in proportion to their ownership interests-for example, AT\&T and the French Administration would own shares equal to the circuits for communication between the United States and France; AT\&T and the German Bundespost would have shares equal to the circuits to be used between the United States and Germany; and AT\&T initially would own a share outright for the circuits going to other countries from the United States. By subsequent agreements, other countries acquired indefeasible rights of use in one or more of the circuits assigned roo per cent to AT\&T upon paying one-half of the capital costs allocable to such circuits and undertaking to pay in the future one-half of the maintenance and operating costs. In addition, circuits have been made available to U.S. international telegraph carriers, who, in turn, have made comparable arrangements with their overseas correspondents.

\section{The Satellite Era in Overseas Communications}

The development which has received the most public attention recently, of course, is that of satellites. This new medium immediately presented great opportunities for an accelerated growth of international communications facilities. AT\&T first demonstrated the transmission of communications by means of active (repeatered) satellites via "Telstar" in Ig62. This provided the first transatlantic television transmission. "Relay," also an active satellite developed by RCA under contract with NASA, was launched on December I3, I962, and was used to televise to Europe the launching of Astronaut L. Gordon Cooper. Shortly thereafter the Communications Satellite Act of 1962 was enacted, establishing a uniquely structured private corporation partly owned by the general public and partly by the United States international carriers to carry out the declared policy of the act "to establish ... as expeditiously as practicable a commercial communications satellite system as part of an improved global communications network." ${ }^{15}$ By r 965 commercial service via satellite was started, and $I 969$ has seen the establishment of global coverage with the completion of the launching of the Intelsat III satellites.

\section{III}

\section{Recent Studies of the Structure of the INDUStRy}

The question of the optimum structure for U.S. international communications has been a matter of active consideration in recent years. As the foregoing review shows, the present structure of a single voice carrier and multiple telegraph carriers is largely the result of the manner and timing of the development of the various

${ }^{16} 47$ U.S.C. $\$ 701$ ( 1962$)$. For the events leading up to the enactment of the Communications Satellite Act of I962, see Moulton, Communications Satellites-The Proposed Communications Satellite Act of 1962, I8 Bus. L. I73, I74-75 (1962). 
physical facilities used. The advent of modern high quality broadband submarine cables had a revolutionary effect on the industry. For the first time there were truly economies of scale, and clear advantages from a service standpoint as well, if the requirements of all of the carriers were combined into the same efficient facilities. It was no longer economic for each carrier to provide its own physical facilities. Furthermore, the growth of new communications requirements, such as those for data transmission, and the feasibility of using the same circuits alternately for voice and data, began to erode the practical separation that had previously existed between the telephone and telegraph businesses. This produced a troubled period for the international telegraph carriers.

In 1959 extensive hearings were held by the Senate Interstate and Foreign Commerce Committee concerning the desirability of a merger of the international telegraph carriers. ${ }^{16}$ No action was taken. Then, in 1963 , Chairman Henry of the FCC called for a "broad-gauged" study of the organization of this country's overseas communications business. ${ }^{17}$ An intragovernmental committee was formed the next year. It retained the Stanford Research Institute to assist in its work. The report of the committee in April 1966 was to the following effect:

The Committee recommends the enactment of permissive merger legislation so that any restructuring which the FCC finds to be in the public interest can be accomplished expeditiously under administrative supervision. Such legislation would remove the present statutory bars to merger of carriers or facilities used to provide overseas telecommunication services and permit the FCC, under appropriate safeguards ... including protection of labor, to approve, as submitted or conditioned, a plan for merger of all or part of such facilities or carriers. ${ }^{18}$

No action was taken on this recommendation. Instead, in August 1967 , President Johnson established the Task Force on Communications Policy, to which reference was made above, and instructed it, among other things, "to investigate whether the present division of ownership in our international communications facilities best serves our needs." 10

As indicated earlier, the Task Force made its report just before President Johnson left office, and the report was subsequently released by the present administration without endorsement. ${ }^{20}$ The Task Force stated that "the policy question posed, to paraphrase Judge Learned Hand's famous phrase, is whether technology has now thrust monopoly upon the international communications industry." It was of the

\footnotetext{
${ }^{10}$ Hearings on Merger of International Telegraph Carriers Before the Senate Comm. on Interstate and Foreign Commerce, 86th Cong., Ist Sess. (I959).

${ }^{17}$ Address by former FCC Chairman William Henry, at meeting of the Standing Committee on Communications of the American Bar Association (FCC Memo 39827, 1963).

${ }^{18}$ Report and Recommendations to Senate aNd House Committees Submitted by the IntraGovernmental Committee on International Telecomunications 3 (April ig66).

${ }^{10}$ Message from the President Transmitting Recommendations Relative to Wordd CommunicaTioNs, Aug. I4, 1967, H.R. Doc. No. I57, 90th Cong., Ist Sess. (1967).

${ }^{20}$ See notes 7 and 8 supra.
} 
opinion that "a basic reorganization of the industry to form a single international transmission entity is desirable, subject to certain safeguards and conditions, in order to assure the achievement of our nation's goals in international communications."21

The merger recommended would be a facility merger only. To be consolidated would be the transmission plant of the international voice and record carriers, Comsat's satellite investments, the U.S. earth stations now operating or planned for operation in international service, and such switching equipment and other equipment as might be justified. The Task Force would leave it up to the international carriers whether they would prefer to go out of business entirely, but it contemplated that

even with consolidated transmission facilities ... competition in rates, service and terminal arrangements can be maintained and fostered by providing users, carriers, and prospectively, perhaps specialized service companies, with flexible access to the international transmission facilities. ${ }^{22}$

The Task Force gave the following five reasons for its recommendation: $:^{23}$

r. It would promote system optimization and enable realization of the available economies of scale.

2. It would further U.S. foreign policy objectives.

3. It would resolve the anomalies of Comsat's role and function.

4. Formation of a single entity would help resolve the problems of the international record industry.

5. Formation of a single entity could improve the prospects of effective government regulation.

Upon analysis these reasons are unpersuasive. The United States has had multiple carriers dealing with foreign telecommunications entities throughout the history of its international communications, and there is no indication it has worked to our disadvantage. Indeed, when the Department of State was asked to comment in r959 on legislation to amend the Communications Act of I934 to permit consolidations or mergers of international telegraph carriers, it expressed the belief that "the bill in question could compromise certain United States foreign economic policy objectives."24 Moreover, the Department of Justice, which opposed the enactment of the proposed legislation, rejected as unsupported and indefensible the argument that "foreign monopolies have a tendency to 'play off' one American company against another in making arrangements for the furnishing of communications services."25

On the domestic front, again it is hard to see what the reason is to seek "to improve the prospects of effective government regulation." The validity of such a

${ }^{31}$ TASR Force Report, supra note 7, ch. 2 at 3.

${ }^{29} \mathrm{Id}$. at 27.

${ }^{20}$ Id. at 27-37.

"Hearings, supra note $I 6$, at 9.

${ }^{25} \mathrm{Id}$. at 22. 
point of course depends upon a case being made that regulation has not been very effective in the past, and such a case is difficult to make in view of the record of improving service and declining rates reviewed above.

Sympathy is expressed for "anomalies" in Comsat's role, but there is nothing new here that was not inherent in the legislative compromises that resulted in the creation of Comsat. The satellite program has moved ahead expeditiously despite, or perhaps in part due to, such "anomalies" as may exist.

Next, it is difficult to determine precisely what the "problems" of the international record industry are that the Task Force believes need resolution. They certainly should not be financial fears of the kind subsequently proven unwarranted, which prompted the FCC in 1959 to reverse its long-standing opposition to merger. ${ }^{26}$ The brief statements on financial matters included at the outset of this article could be supported and expanded upon by reference to the annual reports of the FCC and the Statistics of Communications Common Carriers which it publishes annually. In fact, the Commission has recently written the carriers concerning the level of their earnings. ${ }^{27}$

This leaves the first point, which in any event appears to be the fundamental reason for the Task Force recommendation. In essence, the Task Force seems to have been principally influenced by the coming of age of satellite technology, and a fear that, absent a consolidation of all facility planning and ownership in the same entity, optimal decisions will not be made. ${ }^{27 a}$

That there should be continued development of both cables and satellites is widely recognized and was not disputed by the Task Force. In his message to Congress establishing the Task Force, the President stated,

But this new [satellite] technology-exciting as it is-does not mean that all our surface communications facilities have become obsolete. Indeed, one of the challenges before us is to integrate satellites into a balanced communications system which will meet the needs of a dynamic and expanding world society. ${ }^{28}$

The Satellite Act provides that the framework for satellite communications shall be developed "as part of an improved global communications network." of facility has been expanding dramatically in capacity, and is providing circuits

\footnotetext{
${ }^{20} I d$. at $24-I 68$.

${ }^{27}$ Letter from FCC to all overseas record carriers, July 10, 1969, Ref. No. 9510, and letters of carricrs in response thereto. As this article goes to press, conferences are being held concerning this matter. See 35 Telecommunications Rep., Oct. 6, I969, at I4.

${ }_{27 \Omega}$ Just as this article was going to press, a memorandum with respect to federal policy on domestic satellite communications was sent by Peter Flanigan, assistant to President Nixon, to Dean Burch, Chairman of the Federal Communications Commission, taking the position that the number, or classes, or potential offerers of satellite services should not be limited arbitrarily, and that all prospective entrants whether common carriers, private users, or COMSAT be afforded equal opportunity to establish and operate domestic satellite communications facilities. It specifically rejected coordinated planning or operation of such facilities except as essential to avoid harmful radio interference. N.Y. Times, Jan. 24, 1970, at $\mathrm{I}, \mathbf{5}$.

${ }_{28}$ Message from the PREStDent, supra note i9, at 2.

${ }^{20} 47$ U.S.C. $\$ 701$ (1964) (emphasis added).
} 
at lower and lower cost. For example, the latest submarine cables authorized have a capacity five times as great as the last previous version, and cables providing about 2500 circuits are feasible by about $1975 .^{30}$ Each of the Intelsat III series satellites provides approximately I200 telephone circuits, compared to 240 in the Intelsat II series. An advanced series to be called Intelsat IV is to be ready for launching beginning in I97I, and will still further increase the capacity of the satellite system. ${ }^{31}$

Because of the radically different physical characteristics of satellite systems and cable systems, the economics will favor one type in certain situations and the other in others. Cable costs increase in proportion to distance traversed; satellite system costs are relatively insensitive to distance, etc. Any balanced international rate structure must take these differing characteristics into account.

And there are factors other than economics which must be considered. Cables and satellites are subject to failures and interruptions due to different types of causes. Each can supply vital diversity to the other. Satellite circuits are subject to transmission delays which can be annoying in the case of voice communication, and result in less efficient use in the case of data. On the other hand, the wider bandwidth of satellites make them more suitable for video transmission. Satellites use valuable, scarce radio frequencies; cables do not. Cables may need to transit intermediate countries, whereas satellite communications need not. ${ }^{32}$

Additional "for instances" could be cited, but the basic point is clear: The United States has never put its reliance on the one type of facility domestically, and it should not do so internationally. In this connection, it is interesting to note that after a strong shift from coaxial cable to microwave radio construction in the post-World War II period, the Bell System's domestic construction program is now trending back toward cable construction because the relative economics favor cables in those instances where the requirements are sufficiently large and the rate of growth sufficiently fast to overcome the effects of the higher first costs of cable over radio.

But there is no need to belabor the point. As the Task Force itself concluded:

An efficient international communications system will increasingly require a careful meshing over time of the various methods of transmission-submarine cables, high-frequency radio, satellites and their attendant earth stations, and doubtless other future techniques as well ....33

The question then is, inasmuch as we will have need for many types of facilities in the years ahead, should they be provided and controlled by a single entity as recommended by the Task Force, and particularly, should that entity be

\footnotetext{
${ }^{30}$ Response of AT\&T to Items (h) and (i) in letter of FCC dated Oct. 4, I967, American Tel. \& Tel. Co., 13 F.C.C.2d 235, 237 (1968); TASK FoRCE REPORT, supra note 7, at 8.

${ }^{31}$ The figure of 3500 circuits was used in dealing with the requirement for proportionate fill of the TAT-5 cable and satellite facilities in the Atlantic Basin area. TASK FORCE REPORT, supra note 7, at 243.

${ }^{32}$ For a balanced and comprehensive analysis of the relative advantages of submarine cables and satellites, and the public interest considerations involved, see ITT Cable \& Radio Inc.-Puerto Rico, 5 F.C.C.2d 823 (1966).

${ }^{3 B}$ TASK FORCE REPORT, stupra note 7, at IO.
} 
a facility wholesaler separate from the carriers providing service to the public? With the present structure Comsat is single-mindedly exploiting the new satellite technology. It is doubtful that it would, or could, have moved as expeditiously as it has if its time and talent had been spread over more diverse responsibilities. At the same time, the U.S. international carriers, supported by foreign partners, have continued to press ahead with cable development, and thus is being created a balanced network of both cables and satellites.

At present, should differences of opinion arise as to the appropriate facility to be constructed, there is ample opportunity for diverse views to be marshalled and presented to the appropriate governmental authorities to determine the public interest. For example, in the recent controversy over the authorization for the construction of $\mathrm{TAT}_{5}$, the respective positions of the parties were publicly presented to the Commission, and the views of other agencies of government, such as the office of the Director of Telecommunications Management, the Presidential Task Force on Communications, and the Departments of State and Defense, were considered. $^{34}$ The most recent example of active governmental involvement in the determination of the optimum development of overseas facilities is a series of correspondence commenced by letters addressed to the carriers, the Office of Telecommunications Management, and the Department of State on August 5, 1969, by the Federal Communications Commission. By letter adopted September 17 , 1969 , the Commission requested that negotiations concerning future cables be deferred until certain policy determinations have been made..$^{35}$

As stated above, the industry is health, and the public interest is being well served by rapidly developing technologies which are providing vastly increased communications capability at declining rates. In such circumstances, it would seem that government should be slow to intervene. Over the years consideration has been given to simplifying the structure of the industry by permitting merger of the record carriers to the extent they may desire. Good arguments relating to improved efficiency and economy can be adduced for this proposition, and some public benefits might flow therefrom. ${ }^{36}$ However, there is no need or justification for disrupting the present integrated telephone service by including international telephone facilities in any such merger. From an operating and customer standpoint, the distinction between international and domestic telephone service is rapidly disappearing. ${ }^{37}$ Furthermore, including Comsat in any merger would tend to dilute its present singleminded attention to the rapid development of satellites as a part of a global system, a task far from complete although commendably advanced.

\footnotetext{
${ }^{84}$ American Tel. \& Tel. Co., r3 F.C.C.2d 235, 237-38 (r968).

${ }^{35}$ FCC Public Notice, Report No. 3793 (Sept. 24, I969).

${ }^{80}$ The Department of Justice advised the Federal Communications Commission that it opposes the proposed acquisition of Tropical Radio Telegraph Company by RCA Global Communications. Letter from Department of Justice to the FCC, June 18 , $x 969$.

${ }^{87}$ The first commercial offering of international direct distance dialing will be initiated on January $x_{5}$, r97o. See 35 Telecommunications Rep., July 28, rg69, at 5.
} 